Ǵarībe-hā-ye āšnā. Še 'r-e fārsī-ye Māvarā' ol-nahr qarne bist bā tekiye bar mohit -hā-ye adabi-ye Hoqand va $H^{w}$ àrazm. Tehrān, Mo'assese-ye moțāle‘āt-e mellī, 1384/2006, $333 \mathrm{p}$.

\title{
Aftandil Erkinov
}

\section{(2) OpenEdition}

Journals

Édition électronique

URL : http://journals.openedition.org/abstractairanica/38246

DOI : $10.4000 /$ abstractairanica.38246

ISSN : 1961-960X

Éditeur :

CNRS (UMR 7528 Mondes iraniens et indiens), Éditions de l'IFRI

Édition imprimée

Date de publication : 8 avril 2010

ISSN : 0240-8910

Référence électronique

Aftandil Erkinov, « Garībe-hā-ye āšnā. Še'r-e fārsī-ye Māvarā' ol-nahr qarn-e bīst bā tekiye bar mohịțthā-ye adabī-ye Hoqand va $H^{w}$ ārazm. Tehrān, Mo'assese-ye moțāle'āt-e mellī, 1384/2006, 333 p. », Abstracta Iranica [En ligne], Volume 30 | 2010, document 247, mis en ligne le 08 avril 2010, consulté le 26

septembre 2020. URL : http://journals.openedition.org/abstractairanica/38246 ; DOI : https://doi.org/ 10.4000/abstractairanica.38246

Ce document a été généré automatiquement le 26 septembre 2020.

Tous droits réservés 
Ǵarībe-hā-ye āšnā. Še rr-e fārsī-ye Māvarā' ol-nahr qarn-e bist bā tekiye bar mohịt-hā-ye adabi-ye Hoqand va $H^{w}$ ārazm. Tehrān, Mo'assese-ye moțāle‘āt-e mellī, 1384/2006, 333 p.

\author{
Aftandil Erkinov
}

The present book is devoted to review Persian-language literature of Transoxiana (Mawaraannahr) in the beginning of the 20th century, on the basis of the Kokand and Khivan literary milieus. The subject of the book is literature of the two specified regions. As they were the centers of the two khanates in the 18th-the beginning of the 20th centuries. The author acquaints the readers with history, geography and political situation in Transoxiana; as well as he renders information on the history of its culture and literature. He gives a detailed description of creative poetical work of the poets belonging to the above-mentioned poetical entities. The number of the poets was about 50. They simultaneously wrote in Persian and in Turkic languages. Sometimes they even more wrote in Turkic. The book focuses on Persian-language poetry. By virtue of that a large time-period (and two regions) had been taken as the object of the research the book has a rather familiarization character, the author took the way of a survey depiction of literary communities and poets. The biography and creative work of particular poets (Akhmad Tabibi, Mukhi +) who made a great contribution to the development of the Persian-language poetry in the region are described in more detail. The book provides many poetic fragments and several poems from writings of the poets. Poetic and linguistic styles, originality of poetry in the Persian language in the Khivan and Kokand khanates have been investigated. The book is intended to be used as an educational guidance. 
INDEX

Thèmes : 11.1.0. Généralités

\section{AUTEURS}

AFTANDIL ERKINOV

University of Uzbekistan - Tashkent 